\title{
VERSATILITY OF THE MANURE PHOSPHORUS EXTRACTION (MAPHEX) SYSTEM IN REMOVING PHOSPHORUS, ODOR, MICROBES, AND ALKALINITY FROM DAIRY MANURES: A FOUR-FARM CASE STUDY
}

\author{
C. D. Church, A. N. Hristov, P. J. A. Kleinman, \\ S. K. Fishel, M. R. Reiner, R. B. Bryant
}

\begin{abstract}
Animal manure contains nutrients [primarily nitrogen $(N)$ and phosphorus $(P)$ ] and organic material that are beneficial to crops. Unfortunately, for economic and logistics reasons, most manure tends to be applied to soils near where it is generated. Over time P concentrations in soils where dairy manure is applied builds up, often in excess of crop demands, and its potential loss in runoff poses a risk to water quality. We previously described, and have subsequently built, a full-scale version of a MAnure PHosphorus EXtraction (MAPHEX) System capable of removing greater than $90 \%$ of the P from manures. While originally designed to remove phosphorus, we postulated that the MAPHEX System was also capable of removing odor and microbes, and of concentrating alkalinity into a solid, economically transported form. In this study the MAPHEX System was shown to be highly versatile at removing greater than $90 \%$ of the phosphorus from a wide range of dairy manures. In addition, the study showed that the System is also capable of concentrating and recovering alkalinity from manures, while also removing over $80 \%$ of microbes and reducing the odor of the effluent applied to fields by half.
\end{abstract}

Keywords. Alkalinity, Chemical treatment, Manure, Microbes, Odor, Phosphorus, Treatment systems, Solid separation.

$\mathrm{A}$ nimal manure contains nutrients [primarily nitrogen $(\mathrm{N})$ and phosphorus $(\mathrm{P})]$ and organic material that are beneficial to crops. Unfortunately, the concentrations of those nutrients are too low to make transportation of bulk manures over large distances economically viable, and since dairy manure (and swine manure as well) is typically in slurry form, it must be transported in tanks, making it inconvenient to be hauled as well. For those reasons, dairy manure tends to be applied to soils near where it is generated. Over time, since $\mathrm{P}$ is a

\footnotetext{
(c) $\$($ The authors have paid for open access for this article.

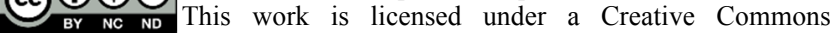
Attribution-NonCommercial-NoDerivatives 4.0 International License https://creative commons.org/licenses/by-nc-nd/4.0/

Submitted for review in September 2017 as manuscript number NRES 12632; approved for publication by the Natural Resources \& Environmental Systems Community of ASABE in March 2018.

The authors are Clinton D. Church, Environmental Chemist, USDAARS Pasture Systems and Watershed Management Research Unit, University Park, Pennsylvania; Alexander N. Hristov, Professor, Pennsylvania State University, College of Agricultural Sciences, University Park, Pennsylvania; Ray B. Bryant, Soil Scientist, Peter J.A. Kleinman, Soil Scientist and Research Leader, Sarah K. Fishel, Support Scientist, and Michael R. Reiner, Hydrologic Technician, USDA-ARS Pasture Systems and Watershed Management Research Unit, University Park, Pennsylvania. Corresponding author: Clinton D. Church, USDAARS Pasture Systems and Watershed Management Research Unit, University Park, PA 16802; phone 814-863-8760; e-mail: clinton.church@ars.usda.gov.
} . 


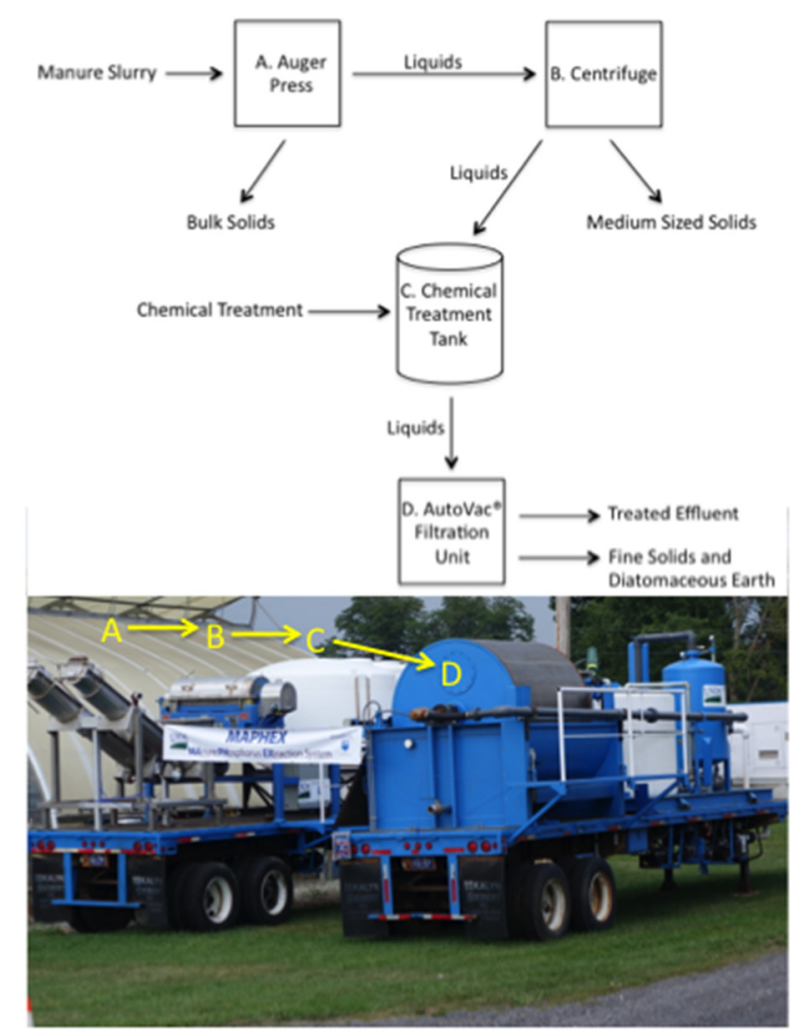

Figure 1. The full-scale MAPHEX System.

\section{Materials ANd Methods THE MAPHEX SYSTEM}

The full-scale MAPHEX System (fig. 1) consists of components to perform: a) an initial liquid-solid separation step broken into two stages, b) chemical treatment, and c) a final liquid-solid separation step using an AutoVac, as well as ancillary components (pumps, piping, etc.). Manure slurry is pumped through the system where manure particulate and $\mathrm{P}$ is removed at each of the liquid-solid separation steps.

a) Initial Liquid-Solid Separation. The initial liquid-solid separation can be done in either one or two stages, depending upon the intended use of the solids and the farm's needs, but it is critical that the overall process leaves only particles smaller than $30 \mu \mathrm{m}$ diameter in the liquid effluent for the following chemical treatment to be effective. In the full-scale MAPHEX System, we use two stages of liquid-solid separation, removing the bulk solids from dairy manure with an auger press (Neptune Enterprises, Richland Center, Wis.) and then removing the medium-sized particles (down to about $25 \mu \mathrm{m}$ diameter) with a decanter centrifuge (Sharples P-3400, Alfa Laval, Lund, Sweden). The reason for using two stages is so that the bulk solids removed by the auger press, which are low in $\mathrm{P}$ relative to the other two solids generated by the system, can be left behind on the farm to be composted and used as bedding material. For farms that do not use the compost for bedding, the bulk solids could be blended with the other solids from the system and sold as fertilizer after composting. Alternatively, the MAPHEX System is designed so that the auger press can be eliminated from the system for those farms that would not utilize the bulk solids or have their own means of separating out those solids, and for farms that have a centrifuge, the system is designed to divert the farm's centrifuge effluent directly to the chemical treatment step.

b) Chemical Treatment. After the initial liquid-solid separation step, the liquids were subjected to chemical treatment $\left[3.0 \mathrm{~g} \mathrm{l}^{-1} \mathrm{Fe}_{2}\left(\mathrm{SO}_{4}\right)_{3}\right]$ to coagulate the particles and to transform dissolved $\mathrm{P}$ (primarily orthophosphate) into a solid form that can be removed in the final liquid solid-separation step. This treatment can either be done in batch mode in tanks, or could be accomplished by injecting the chemicals into the liquid stream.

c) Final Liquid-Solid Separation. The final liquid-solid separation removes the $\mathrm{P}$ converted in the chemical treatment step along with the fine solids (those between 0.5 and $25 \mu \mathrm{m}$ diameter). The only existing technology we identified that was capable of performing this step while simultaneously yielding a stackable solid was an AutoVac $^{\circledR}$ AV660 unit manufactured by ALAR Engineering Corporation (Mokena, Ill.). This unit uses a rotating drum of diatomaceous earth (DE) that has pore spaces of approximately $0.5 \mu \mathrm{m}$ and is designed so that the filtration surface is constantly renewed.

\section{Manures Tested}

In order to demonstrate the versatility of the MAPHEX System, we purposely chose to use farms that varied widely in herd size, bedding type used, and in the existing methods of manure treatment and handling so as to represent manures common throughout the dairy industry. Herd size ranged from 90 to 5500 milking cows, bedding on the farms was either fresh sawdust or composted manure, and existing manure treatment on the farms ranged from storage only (the 90-cow farm), to bulk liquid-solid separation aimed at bedding recovery (the 2700-cow farm), to anaerobic digestion followed by bulk liquid-solid separation for bedding recovery (the 5500-cow farm). In cases where the existing technology performed a similar function as components of the MAPHEX System (such as bulk liquidsolid separation), we bypassed that component of the MAPHEX System, and fed the effluent from the farms treatment technology directly to the next component of the MAPHEX System.

\section{0-Cow Dairy}

The MAPHEX System was used to treat manure on a dairy farm in eastern Pennsylvania with 90 lactating Holstein dairy cows housed in a free stall barn with slots in the floor allowing manure to fall directly into the manure storage pit below the barn. Manure from an attached free stall barn housing 40 non-lactating cows is also regularly scraped into the pit. All free stalls are regularly bedded with fresh sawdust. Wash water from the milking parlor is stored underneath a slotted floor in the holding pen outside the milking parlor. This is pumped to the storage pit when the pit is full. Dairy manure was pumped directly from the 
manure storage pit (22-25 May 2017) into the two auger presses of the MAPHEX System. Liquid effluent from the auger presses (minus the rejected solids) gravity fed into a holding tank and were subsequently pumped through the complete MAPHEX System.

\section{0-Cow Dairy}

Manure slurry was obtained from a dairy farm in central Pennsylvania with 150 lactating Holstein dairy cows housed in a free stall barn that was regularly bedded with coarse wood chips. Dairy manure was scraped daily into a holding pit and water was added once per week to the pit to transfer manure to an aboveground slurry holding tank. Manure from the open slurry holding tank was agitated for approximately $24 \mathrm{~h}$, then was transferred to a $8,800 \mathrm{~L}$ recirculating tanker (29 August 2017) and transported offsite for use as source for the MAPHEX System.

\section{0-Cow Dairy}

The dairy on which we treated manure was located in central Pennsylvania and had approximately 2700 lactating Holstein dairy cows housed in free stall barns. Manure from the barns was scraped into a holding pit, where water was added and was transferred continually to an open holding tank, where it was fed continually to an on-farm screw press for liquid-solid separation. Since the screw press performs much the same function as our auger presses, manure from the holding tank after the screw press was pumped directly into the centrifuge of the MAPHEX system for testing on 20-23 June 2017. One major difference in this dairy's manure treatment compared to the other two dairies is that they amend their solids from the screw press with lime for bacterial control during composting for use as bedding. The added lime results in manure slurry with an elevated alkalinity when portions of those amended solids inevitably end up back in the manure slurry. This farm requested that we also try to recover some of this alkalinity in a solid form which would be beneficial to them. Alkalinity recovery testing was performed as described above on 15 May 2017.

\section{0-Cow Dairy}

The largest dairy from which we used manure was located in eastern Wisconsin and had approximately 5500 lactating Holstein dairy cows housed in free stall barns. Manure from the barns was scraped into a holding pit and mixed with dairy parlor wash before being fed into a large underground anaerobic digester. Manure leaving the digester was fed to an on-farm screw press for solids removal and fed down a pipe to a storage lagoon. Manure from this pipe was pumped directly into the centrifuge of the MAPHEX system for testing on 11-13 July 2017.

\section{SAMPle COllection/Preservation AND LABORATORY ANALYSIS \\ Sample Collection and Preservation}

Samples were taken of the raw dairy manure slurry, and of effluents and solids removed by the liquid-solid separation steps to test for solids content and $\mathrm{P}$ and $\mathrm{N}$ concentrations (discussed below). Raw manure slurry samples were collected from a well-stirred tank or lagoon, while effluent and solid reject samples were collected periodically during the operation of the MAPHEX System. All samples were stored at $4^{\circ} \mathrm{C}$ until analyzed.

\section{EPA $3050 b$ P Determination}

Samples were subjected to EPA 3050B extraction for P and Kjeldahl digest $\mathrm{N}$ (TKN) analysis. Briefly, manure slurries and solids were extracted with aqua regia and hydrogen peroxide following a modified EPA Standard Method 3050B (Kimbrough and Wakakuwa, 1989). Solids were oven dried at $110^{\circ} \mathrm{C}$ for $16 \mathrm{~h}$ to determine solids content, but were digested wet, such that the sample size contained $0.5 \mathrm{~g}$ of solid material. Liquid effluents were treated as water samples using $10 \mathrm{~mL}$ of sample. Following dilution to final volumes and filtration (Whatman No. 1), P analysis was then performed on all extracts using an inductively coupled optical emission spectrophotometer (ICP-OES, Varian).

\section{Kjeldahl Digest $\mathbf{N}$ Determination}

Extractions were also carried out for Total Kjeldahl $\mathrm{N}$ (TKN) determination (Gallaher et al., 1976; Peters, 2003). Briefly, a 0.5 g solids-weight of material was weighed into digestion tubes and $3.5 \mathrm{~g} \mathrm{~K}_{2} \mathrm{SO}_{4}, 0.4 \mathrm{~g} \mathrm{CuSO}_{4}$, and $7 \mathrm{~mL}$ of concentrated sulfuric acid were added. The sample was then digested at $375^{\circ} \mathrm{C}$ for $2 \mathrm{~h}$ and diluted to final volume. After filtration (Whatman No. 1), N analysis was then performed by Quick Chem Method 10-107-06-2-H (Lachat Instruments, 2003).

\section{Calcium Carbonate Equivalent Determination}

Alkalinity was tested upon the request of one of the farms (2700-cow dairy) to determine if the MAPHEX System could isolate a solid material that had a high concentration of $\mathrm{P}$ that also had high alkalinity, as they had a specific use in mind for such a solid. To make this determination, raw manure samples and samples from effluents and rejects of various stages of the MAPHEX System were preserved on ice and delivered to the Pennsylvania State University's Agricultural Analytical Services Laboratory within $24 \mathrm{~h}$ of collection. Samples were analyzed for alkalinity by titration by ASTM Standard Methods (ASTM C25, 1999), and expressed as Calcium Carbonate Equivalence.

\section{Microbial Determination}

At two of the farms (the 90- and 2700- cow dairies) samples were taken to test for reduction of Total Coliforms and E. coli. Raw manure and MAPHEX final effluent samples were preserved on ice, subjected to serial dilution, and delivered to the Pennsylvania State University's Agricultural Analytical Services Laboratory within $24 \mathrm{~h}$ of collection. Most probable number determinations for Total Coliforms and E. coli were performed using Quantitray/2000 (Quantitray/2000, 2013) trays and Most Probable Number Table using a standard methodology outlined by the manufacturer (Idexx, Westbrook, Maine).

\section{Odor Determination}

At two of the farms (the 90- and 2700-cow dairies) samples were taken to test for odor reduction by the MAPHEX System. Raw manure, solid rejects, and liquid 
effluent samples were preserved on ice and delivered to the Pennsylvania State University's Odor Assessment Laboratory within $5 \mathrm{~h}$ of collection. Upon receiving the samples, $400 \mathrm{~g}$ of each material, as well as a blank odor sample (400 g distilled water), were placed in separate glass vessels and brought to $20^{\circ} \mathrm{C}$ in a water bath. Air samples were collected in 10-L Teflon bags from the headspace of each sample vessel using a steady state flux chamber system. Vessel headspaces were subjected to a sweep airflow rate of $2 \mathrm{~L} / \mathrm{min}$ until three to five headspace volume exchanges occurred prior to sample collection. Detection threshold (DT) levels were recorded for each sample (presented in random order) by least five certified odor assessors for each sample on the same day of collection of the headspace air sample per standardized methods (St. Croix Sensory, 2003).

\section{Data ANalysis}

Nutrient removal efficiencies were determined from a mass balance approach comparing influent loads with observed loads in effluent liquids and solid rejects at each step of the manure treatment process, where samples were taken at a minimum of $30 \mathrm{~min}$ apart during a days testing. Means and standard errors reported were calculated by an Excel spreadsheet. Standard errors and groupings noted in odor threshold assessment were calculated by SigmaPlot.

\section{RESULTS AND DISCUSSION}

\section{PHOSPHORUS AND SOLIDS REMOVAL}

Overall $\mathrm{P}$ removal ranged from $90 \%$ to $93 \%$ removal for all farms tested (table 1), while $\mathrm{N}$ removal was less than $8 \%$ (mass basis) for all farms (data not shown). In all cases, solids removed from the manure slurry by various machinery were stackable, containing between $70 \%$ and
$75 \%$ moisture. Phosphorus removal in bulk solids by existing farm screw presses accounted for $16 \%$ and $17 \%$ at the 5500- and 2700-cow dairies, respectively, while $\mathrm{P}$ removal by the MAPHEX auger press was slightly lower at $15 \%$ on the 90 -cow farm and considerably lower $(9 \%)$ on the 150-cow farm, presumably due to high influent flow to the press. Note also that this is consistent with the relative amount of solids removed at the corresponding farms. Also note that the concentrations in the auger press effluent relative to the raw manure actually increased for the two farms that bed on fresh sawdust and wood chips (the 90and 150-cow farms) instead of manure compost due to the solids removed having a much lower $\mathrm{P}$ concentration than the liquid fraction.

Further inspection of the data suggests that the centrifuge may not have been operated in an optimal way during the onsite testing at the 90- and 2700-cow farms. This is evidenced in the low values of $\mathrm{P}$ removed by the centrifuge $(15 \%$ and $21 \%)$ compared to the other farms $(31 \%$ and $32 \%$ ). This suggests that, in our testing, the manure flow to the centrifuge of $150 \mathrm{~L} \mathrm{~min}^{-1}$ as opposed to $95 \mathrm{~L} \mathrm{~min}^{-1}$ at the other two farms was actually higher than optimal and resulted in less $\mathrm{P}$ being removed by the centrifuge than otherwise may have. Despite the differences seen in centrifuge $\mathrm{P}$ removal, and the varying $\mathrm{P}$ concentration fed to the AutoVac ${ }^{\circledR}$ at the different farms, it was capable of removing most of the remaining $\mathrm{P}$ (from $43 \%$ to $61 \%$ ).

\section{ALKALINITY CONCENTRATION AND RECOVERY}

As previously mentioned, the 2700-cow dairy uses a McClanahan screen separator followed by a screw press to recover manure solids as bedding, amending with large amounts of lime to control bacteria. While they find this beneficial for herd health, their current system has large amounts of lime (alkalinity) and phosphorus (P) in their

Table 1. P removal in effluent of steps/stages of MAPHEX System.

\begin{tabular}{|c|c|c|c|}
\hline Manure/Effluent (90-cow dairy) & $\begin{array}{c}\text { Solids } \\
(\%)\end{array}$ & $\begin{array}{l}\text { 3050B Extractable P }\left(\mathrm{mg} \mathrm{kg}^{-1}\right) \\
\text { (Mean, St. Error, } \mathrm{n} \text { ) }\end{array}$ & $\begin{array}{c}\text { 3050B Extractable P Removed } \\
(\%)\end{array}$ \\
\hline Raw manure & 12.9 & $271.1,9.6,9$ & 0 \\
\hline Auger Press effluent & 6.2 & $316.4,10.8,8$ & 15 \\
\hline Centrifuge effluent & 3.2 & $195.8,3.2,10$ & 15 \\
\hline AutoVac ${ }^{\circledR}$ effluent & 1.4 & $24.8,1.4,10$ & 61 \\
\hline Overall percent removal & & & 91 \\
\hline \multicolumn{4}{|l|}{ Manure/Effluent (150-cow dairy) } \\
\hline Raw manure & 5.2 & $371.7,1.52,3$ & 0 \\
\hline Auger Press effluent & 4.9 & $373.0,1.81,5$ & 9 \\
\hline Centrifuge effluent & 2.3 & $218.6,0.78,6$ & 32 \\
\hline AutoVac ${ }^{\mathbb{B}}$ effluent & 0.4 & $27.7,0.80,12$ & 52 \\
\hline Overall percent removal & & & 93 \\
\hline \multicolumn{4}{|l|}{ Manure/Effluent (2700-cow dairy) } \\
\hline Raw manure & 5.2 & $333.5,3.3,2$ & 0 \\
\hline Screw press effluent & 4.3 & $275.9,1.0,4$ & 17 \\
\hline Centrifuge effluent & 3.0 & $205.6,4.0,6$ & 21 \\
\hline AutoVac ${ }^{\circledR}$ effluent & 0.75 & $27.8,0.73,16$ & 53 \\
\hline Overall percent removal & & & 91 \\
\hline \multicolumn{4}{|l|}{ Manure/Effluent (5500-cow dairy) } \\
\hline Raw manure & 6.4 & $618.3,15.3,4$ & 0 \\
\hline Digester screw press effluent & 3.8 & $520.1,9.5,7$ & 16 \\
\hline Centrifuge effluent & 2.7 & $328.4,3.81,9$ & 31 \\
\hline AutoVac ${ }^{\mathbb{Q}}$ effluent & 1.1 & $64.2,1.7,24$ & 43 \\
\hline Overall percent removal & & & 90 \\
\hline
\end{tabular}


screw press effluent, resulting in $\mathrm{pH}$ and $\mathrm{P}$ build up on the surface of their soils when spread. They also had additional fields, remote from the dairy barns, needing both alkalinity and $\mathrm{P}$ amendment. At their request, we sought to determine whether alkalinity (expressed as Calcium Carbonate Equivalent, CCE) and P could be recovered in a solid, compact, easily transported and spreadable form.

While the AutoVac ${ }^{\circledR}$ showed superior recovery of alkalinity (44\%) compared to the centrifuge solids (Table 2 ), recovery and re-use of the DE contained in those solids is preferable to spreading on fields in order to reduce daily operating costs. However, on-site MAPHEX testing revealed that, at least $22 \%$ additional alkalinity and $21 \% \mathrm{P}$ could be economically recovered as a solid from dairy manure slurry using a decanter centrifuge after the farm's existing screw press (tables 1 and 2). These centrifuge solids could likely be applied using a wet lime spreader, resulting in greater opportunities for land application across their extensive operation ( $\sim 1000$ acres cannot currently receive manure due to distance and accessibility). Furthermore, the data suggests that if the centrifuge had been operated with a lower inflow rate (discussed previously), both $\mathrm{P}$ and alkalinity recovery by the centrifuge would be significantly higher.

\section{Microbial Reduction}

Onsite testing showed that the approximate $0.5 \mu \mathrm{m}$ pore size of the AutoVac ${ }^{\circledR}$ diatomaceous earth filter used in the MAPHEX System was also capable of removing total coliforms and E. Coli from dairy manures. The most probable numbers of total coliforms were reduced by $84 \%$ and $79 \%$, respectively, at the $90-$ and 2700 -cow dairies, while $E$. coli most probable numbers were reduced by $86 \%$ and $80 \%$, respectively (table 3 ). This is likely due to a combination of bacterial size in comparison to the pore size of the filter, and the bacteria's preferential attachment to manure particles.

\section{Odor Reduction}

An ongoing concern that dairies face when spreading manure near towns or other urban developments is complaints about odor from their neighbors. Therefore, any

Table 2. Calcium carbonate equivalent removal effluent of steps/stages of MAPHEX System.

\begin{tabular}{lccc}
\multicolumn{4}{c}{ effluent of steps/stages of MAPHEX System. } \\
\hline $\begin{array}{c}\text { Manure/Effluent } \\
(2700 \text {-cow dairy) }\end{array}$ & $\begin{array}{c}\text { Solids } \\
(\%)\end{array}$ & $\begin{array}{c}\text { CCE:CCE } \\
\text { (mass basis, \%) }\end{array}$ & $\begin{array}{c}\text { CCE Removed } \\
\text { (mass basis, \%) }\end{array}$ \\
\hline Raw manure & 7.9 & 1.60 & 0 \\
Screw press effluent & 7.6 & 1.39 & 13 \\
Centrifuge effluent & 4.0 & 1.04 & 22 \\
AutoVac ${ }^{\mathbb{Q}}$ effluent & 0.5 & 0.34 & 44 \\
Overall percent removal & & & 79 \\
\hline
\end{tabular}

Table 3. Total coliform and $E$. coli removal by MAPHEX System.

\begin{tabular}{lcc}
\hline \multicolumn{1}{c}{$\begin{array}{c}\text { Manure/Effluent } \\
\text { (90-cow dairy) }\end{array}$} & $\begin{array}{c}\text { Total Coliforms } \\
\text { (MPN per 100 mL) }\end{array}$ & $\begin{array}{c}\text { E. coli } \\
\text { (MPN per 100 mL) }\end{array}$ \\
\hline Raw manure & $14.2 \times 106$ & $12.7 \times 106$ \\
AutoVac ${ }^{\circledR}$ effluent & $2.3 \times 106$ & $1.8 \times 106$ \\
Overall percent removal & $84 \%$ & $86 \%$ \\
\hline \multicolumn{1}{c}{$(2700$-cow dairy) } & & \\
\hline Raw manure & $10.5 \times 106$ & $6.5 \times 106$ \\
AutoVac ${ }^{\circledR}$ effluent & $2.3 \times 106$ & $1.3 \times 106$ \\
Overall percent removal & $80 \%$ & $81 \%$ \\
\hline
\end{tabular}

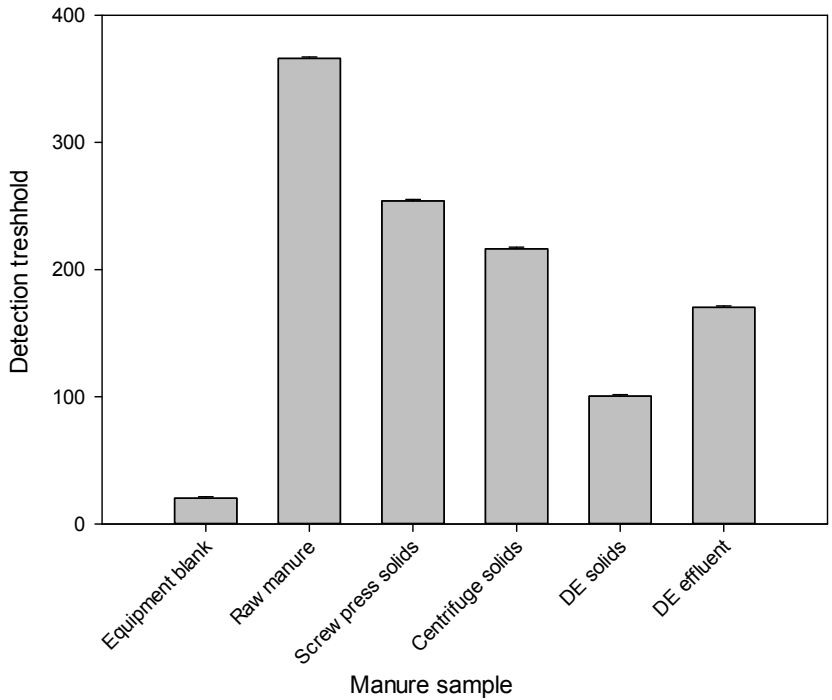

Figure 2. Detection threshold for MAPHEX manure fractions (combined data for two dairies sampled summer 2017).

reduction in the odor of manure that is spread on fields is welcome. We found that all the products from the MAPHEX system had significantly less odor than raw manure (fig. 2), and that the product with the largest volume by far (the AutoVac ${ }^{\circledR}$, or 'DE' Effluent) had a detection threshold of about half that of raw manure. This reduction in odor is also likely due to the way the AutoVac ${ }^{\circledR}$ operates. Manure effluent is pulled through the diatomaceaous earth filter to the interior of the drum and then runs down the inside of the drum in a thin sheet. The high surface area relative to the volume of this thin sheet, coupled by the approximate $22 \mathrm{~mm}$ of vacuum pressure on the interior of the drum allows volatile odiferous compounds to escape the liquid and be vented into the atmosphere near the source of manure rather than be widely spread on receiving fields.

\section{IMPLICATIONS}

The MAPHEX System was shown to remove greater than $90 \%$ of the phosphorus from a wide range of dairy manures while retaining greater than $90 \% \mathrm{~N}$ in the effluent for the beneficial use by the farmer. This resulting final effluent can be beneficially used for fertigation, as most of the negative aspects of raw manure have been reduced.

The solids removed by each stage of the MAPHEX System also have beneficial uses. Bulk solids (typically about $80 \%$ of total solids) removed by the MAPHEX System auger presses or by on-farm screw presses contain relatively low amounts of $\mathrm{P}(9 \%-17 \%$ in this study), and are often a valuable resource to farmers to use as composted bedding material. The centrifuge and AutoVac ${ }^{\mathbb{B}}$ solids (each about $10 \%$ of total solids) contain considerably higher amounts of $\mathrm{P}(21 \%-32 \%$ and $43 \%-53 \%$, respectively, in this study). These high $\mathrm{P}$ solids also have multiple potential uses that are beneficial, including:

1) The dairy farmers themselves. Concentrating manure phosphorus into a more compact form cuts their fuel costs considerably, allowing them to economically 
transport phosphorus to fields far from the dairy that need phosphorus, while allowing the much greater volume of liquid to be applied to fields close to the dairy that need nitrogen but over the course of time have become saturated with phosphorus. This option does not remove phosphorus from the watershed, but does provide for phosphorus to be applied on soils that are more likely to retain it.

2) Nursery and mushroom industries. Reports from dairies that have an operating centrifuge indicate that the centrifuge solids are a highly sought-after commodity by nurseries and mushroom farmers. This would also be true of the AutoVac ${ }^{\circledR}$ solids produced by MAPHEX, which have the added benefits associated with diatomaceous earth.

3) Local organic farmers. Composted solids from MAPHEX would make an ideal organic soil amendment.

4) Retail. Composted and bagged, MAPHEX solids can be sold in garden centers similar to composted steer manure.

5) Energy generation. Once the solids are dried to about $30 \%$ moisture, they make an ideal feedstock for energy generation. This option also concentrates the phosphorus into a very compact form (residual ash) that can serve as a highly compact form of phosphorus and trace element fertilizer.

The full-scale MAPHEX System showed high versatility in treating manures from farms that varied widely in herd size, bedding type used, and in the existing methods of manure treatment and handling. For farms that had manure treatment analogous to some components of the MAPHEX System, that component was simply bypassed, with the farms effluent being pumped directly to the next component of the system. In addition to that, the study showed that the system is also capable of concentrating and recovering alkalinity from manures, while also removing a significant amount of microbes and odor from the effluent.

\section{ACKNOWLEDGEMENTS AND DISCLAIMER}

This work presented here is covered by Patent Application Number 14665229, filed March 23, 2015, and Patent Pending as of August 28, 2017. Special thanks are extended to David Otto (retired), who contributed significantly to the design of both the prototype and full-scale MAPHEX Systems. Funding for this study was provided by a Research Applications for INnovation (RAIN) Grant from the Pennsylvania State University Foundation.

Mention of trade names or commercial products in this publication is solely for the purpose of providing specific information and does not imply recommendation or endorsement by the U.S. Department of Agriculture (USDA). USDA is an equal opportunity provider and employer. The U.S. Department of Agriculture prohibits discrimination in all its programs and activities on the basis of race, color, national origin, age, disability, and where applicable, sex, marital status, familial status, parental status, religion, sexual orientation, genetic information, political beliefs, reprisal, or because all or part of an individual's income is derived from any public assistance program. (Not all prohibited bases apply to all programs.) Persons with disabilities who require alternative means for communication of program information (Braille, large print, audiotape, etc.) should contact USDA's TARGET Center at (202) 720-2600 (voice and TDD). To file a complaint of discrimination, write to USDA, Director, Office of Civil Rights, 1400 Independence Avenue, S.W., Washington, D.C. 20250-9410, or call (800) 795-3272 (voice) or (202) 720-6382 (TDD).

\section{REFERENCES}

ASTM. (1999). C25: Standard test methods for chemical analysis of limestone, quicklime, and hydrated lime, section 33 . West Conshohocken, PA: ASTM Int.

Church, C. D., Hristov, A. N., Bryant, R. B., Fishel, S. K., \& Kleinman, P. J. A.(2016). A novel treatment system to remove phosphorus from liquid manure. Appl. Eng. Agric., 32(1), 103112. https://doi.org/10.13031/aea.32.10999

Church, C. D., Hristov, A., Bryant, R. B., \& Kleinman. P. J. A. (2017). Processes and treatment systems for treating high phosphorus containing fluids. Patent Application No. 14665229. Attorney Docket Number 0045.14.

Gallaher, R. N., Weldon, C. O., \& Boswell, F. C. (1976). A semiautomated procedure for total nitrogen in plant and soil samples. SSSAJ, 40(6), 887-889. https://doi.org/10.2136/sssaj1976.03615995004000060026x

Kimbrough, D. E., \& Wakakuwa, J. R. (1989). Acid digestion for sediments, sludges, soils, and solid wastes. A proposed alternative to EPA SW 846 method 3050. Environ. Sci. Technol., 23(7), 898-900.

Kleinman, P., Blunk, K. S., Bryant, R., Saporito, L., Beegle, D., Czymmek, K.,... Smith, M. (2012). Managing manure for sustainable livestock production in the Chesapeake Bay Watershed. JSWC, 67(2), 54A-61A. https://doi.org/10.2489/jswc.67.2.54A

Lachat Instruments. (2003). Determination of total Kjeldahl nitrogen by flow injection analysis. Quick Chem Method 10107-06-2-H. Loveland, CO: Lachat Instruments.

Pagliari, P. H., \& Laboski, C. A. (2012). Investigation of the inorganic and organic phosphorus forms in animal manure. JEQ, 41(3), 901-910. https://doi.org/10.2134/jeq2011.0451

Pagliari, P. H., \& Laboski, C. A. (2013). Dairy manure treatment effects on manure phosphorus fractionation and changes in soil test phosphorus. Biol. Fertil. Soils, 49(8), 987-999. https://doi.org/10.1007/s00374-013-0798-2

Peters, J. (Ed.) (2003). Recommended methods of manure analysis. Bulletin A3769. Madison, WI: University of Wisconsin Ext. Cooperative Ext. Publ.

QuantiTray/2000. (2013). Insert and most probable number table. Retrieved from https://www.idexx.com/resourcelibrary/water/quanti-tray-2000-procedure-en.pdf

Sharpley, A. N., Chapra, S. C., Wedepohl, R., Sims, J. T., Daniel, T. C., \& Reddy, K. R. (1994). Managing agricultural phosphorus for protection of surface waters: Issues and options. JEQ, 23(3), 437-451. https://doi.org/10.2134/jeq1994.00472425002300030006x

St. Croix Sensory. (2003). A detailed assessment of the science and technology of odor measurement. Lake Elmo, MN. Retrieved from http://www.pca.state.mn.us/publications/p-gen2-01.pdf 